\title{
HYGROSCOPIC PROPERTIES FOLLOWING DRYING AFFECTS WOOD CONSUMPTION BY Odontotermes obesus
}

\author{
Sohail Ahmed', Syed Khawar Abbas Naqvi², Ali Akbar Sherazi², Babar Hassan", \\ Muhammad Asam Riaz ${ }^{3,4}$, Muhammad Zeeshan Majeed ${ }^{3,4}$
}

\begin{abstract}
The relationship between drying and hygroscopic ability of Crateva adansonii and Populus deltoides woods to resist feeding by Odontotermes obesus was studied. Woods were dried under the sun and in the oven for a range of 5-25 days and then these were exposed to termites for 25 days in underground pits in Randomized Complete Block Design pattern with five replications. Results showed that lowest moisture gain was observed at a short time for drying with each method. Weight loss after termites' exposure was more in less dried sap and heartwood of either plant species. The practical implication of these results is discussed.
\end{abstract}

Keywords: Crateva adansonii, hygroscopicity, moisture content, Populus deltoids, consumption, termites, field test.

\section{INTRODUCTION}

Like many biological materials, wood being hygroscopic, absorbs moisture from the wet environment and even saturated wood loses moisture in a dry environment (Akyildiz and Ates 2008). Hygroscopic properties of wood vary according to extractives present in wood (Quartey 2015). Heat treatment is a useful method to reduce hygroscopicity, however, the effects of heating are sometimes reversible i.e. recoverable by mild after-treatments such as moistening and soaking in organic solvents (Obataya 2014). In addition to heat treatment, another useful method to overcome shortcomings of heating is impregnating wood with appropriate hydrophobes (Mantanis and Papadopoulos 2010). On the other hand, heat treatment of wood increases its ability to store and transport free water. Subterranean termites construct tunnels in the outer surfaces of the wood leading to an increase of its moisture content, mainly in the areas of contact with termites. Heat treatment causes wood components degradation, facilitating termite access to free sugars (Surini et al. 2011, Duarte et al. 2012, 2016).

It is generally stated that wood with less than $20 \%$ moisture content is not susceptible to termites (Clausen 2010, Sivrikaya et al. 2015). In most cases, heat treated wood in contact with soil resists weight loss by feeding of termites (Scouse et al. 2015). There are also reports where weight loss increases with time when woods were in contact with soil. The survival time of termites, Reticulitermes flavipes, increased with the rise in wood moisture content without soil contact in high humidity environment.

${ }^{1}$ Professor, Department of Entomology, University of Agriculture. Faisalabad. Pakistan

${ }^{2}$ Department of Entomology, University of Agriculture. Faisalabad. Pakistan

${ }^{3}$ Assistant Professor ,University College of Agriculture, University of Sargodha, Sargodha. Pakistan .

${ }^{4}$ Termite Management Laboratory, Department of Entomology, University of Agriculture. Faisalabad, Pakistan.

•Corresponding author: sialuaf@gmail.com

Received: 04.01.2016 Accepted: 17.07.2016 
Wood MCs below 24\% were lethal to R. flavipes, because moisture in wood was not suitable for termites infestation with no soil contact, probably because water obtained from the wood by termite feeding does not compensate for water loss from their bodies, regardless of relative humidity in the air-space (McManamy et al. 2008). Wood and termite nesting materials with $>16 \%$ moisture content (MC) cause the air spaces within these structures to be saturated with moisture (Sponsler and Appel 1990). This would guarantee termite survival if water loss by cuticular permeability represents the major process for desiccation.

Wood hygroscopicity may be responsible for reporting an increase in weight loss and termites' infestation when samples are in contact with the ground and thus, may counterbalance the advantage of heat treatment. Infestation of Odontotermes obesus (Ramb.) on heat treated wood was greater than non-heated ones (Sheikh et al. 2010). This may be an artifact in experiment where hygroscopicity was not considered. Thus, present studies were aimed to determine hygroscopicity of two kinds of wood after exposure to heat (drying) and then later placed in an underground pit to observe weight loss and termites' infestation and compared with non-dried / control woods.

\section{MATERIALS AND METHODS}

Logs of Crateva adansonii (barna) and Populus deltoides (poplar) woods were cut into smaller blocks of sap and heartwoods; portions of $13 \times 5 \times 2 \mathrm{~cm}$ dimension were obtained by using an electric saw. Moisture content (MC) of freshly cut blocks of both kinds of wood was measured by oven drying method until constant weight was achieved.

Heart and sap woods of both $C$. adansonii and P. deltoides were sun and oven dried for 5, 10, 15, 20 and 25 days at $100^{\circ} \mathrm{C}$. In sun drying method, blocks were put on blotting paper under a glass cover and kept exposed to the sun for above said periods. At the end of each drying time, blocks were removed and put on a concrete surface in the underground pits (Fatima et al. 2015) to determine moisture gain. Pits were also meant to expose blocks to termites' access and $O$. obesus was termites' species in this particular site of Postgraduate Agriculture Research Station, Jhang Road, Faisalabad. The moisture gain in wooden blocks and weight loss due to termites' feeding were carried out in separate laid out experiments. The blocks remained in pits for either purpose for 25 days. Moisture gain and weight loss were calculated from following formulae (Hartley and Marchant 1995).

$$
\text { Moisture gain }(\%)=\frac{W_{1}-W_{2}}{W_{2}} \times 100
$$

$\mathrm{W}_{1}$ : Oven dried weight before exposure

$\mathrm{W}_{2}$ : Oven dried weight after exposure

$$
\text { Weight loss }(\%)=\frac{W_{1}-W_{2}}{W_{1}} \times 100
$$

$\mathrm{W}_{1}$ : weight before feeding of termites

$\mathrm{W}_{2}$ : weight after feeding of termites

All the treatments in two experiments were arranged in Randomized Complete block design with five replications. The means of significant interaction among the parameters were compared by using Tukey's Highly Significant Difference (HSD) test for paired comparisons at a probability level of $5 \%$ by Minitab 17. Pearson's linear correlation coefficient ( $\mathrm{r}$ ) was used to determine the relationship between moisture content and wood weight loss. 


\section{RESULTS AND DISCUSSION}

Oven and sun drying, heart and sapwood and duration of drying had significant differences of moisture gain in $C$. adansonii at post 25 days interval. Interaction among drying methods, wood types and time for drying was non-significant $(\mathrm{p}>0,05)$ (Table 1). With the increase in duration for drying, moisture gain was also increased. Lowest moisture gain was observed at a short time for drying with each method. Moisture gain in either drying method was significantly different from their corresponding controls (Table 2).

Table 1. ANOVA of moisture gain in Crateva adansonii and Populus deltoides after 25 days exposure.

\begin{tabular}{|l|l|l|l|}
\hline & & C. adansonii & P. deltoides \\
\hline SOV & DF & MS & MS \\
\hline Drying Method (DM) & 3 & $378,33^{*}$ & $413,51^{*}$ \\
\hline Wood types (WT) & 1 & $23,18^{*}$ & $24,35^{*}$ \\
\hline Drying times (DT) & 4 & $169,56^{*}$ & $241,32^{*}$ \\
\hline DM x WT & 3 & $0,30^{\text {ns }}$ & $0,17^{\text {ns }}$ \\
\hline DM x DT & 12 & $6,09^{*}$ & $2,74^{*}$ \\
\hline WP x DT & 4 & $0,47^{\text {ns }}$ & $0,36^{*}$ \\
\hline DM x WT x DT & 12 & $0,34^{\text {ns }}$ & $0,10^{\text {ns }}$ \\
\hline Error & 80 & 0,26 & 0,08 \\
\hline Total & 119 & & \\
\hline
\end{tabular}

Table 2. Comparison of means for moisture gain in Crateva adansonii with oven and sun drying at different drying durations.

\begin{tabular}{|l|l|l|l|l|}
\hline DT & \multicolumn{4}{|c|}{ Drying Methods } \\
\hline & Oven drying & Control & Sun drying & Control \\
\hline 5 & $3,95 \pm 0,24 \mathrm{f}$ & $0,26 \pm 0,06 \mathrm{j}$ & $3,29 \pm 0,25 \mathrm{fg}$ & $0,22 \pm 0,05 \mathrm{j}$ \\
\hline 10 & $6,87 \pm 0,24 \mathrm{c}$ & $0,91 \pm 0,32 \mathrm{ij}$ & $6,35 \pm 0,23 \mathrm{~cd}$ & $0,57 \pm 0,07 \mathrm{j}$ \\
\hline 15 & $10,20 \pm 0,27 \mathrm{~b}$ & $2,28 \pm 0,56 \mathrm{gh}$ & $9,80 \pm 0,26 \mathrm{~b}$ & $1,96 \pm 0,27 \mathrm{hi}$ \\
\hline 20 & $10,84 \pm 0,25 \mathrm{ab}$ & $3,25 \pm 0,58 \mathrm{fg}$ & $10,46 \pm 0,23 \mathrm{~b}$ & $3,93 \pm 0,24 \mathrm{f}$ \\
\hline 25 & $11,92 \pm 0,28 \mathrm{a}$ & $5,37 \pm 0,26 \mathrm{de}$ & $11,69 \pm 0,26 \mathrm{a}$ & $5,20 \pm 0,31 \mathrm{e}$ \\
\hline
\end{tabular}

Values are Means \pm SE. Means sharing same letters are not significantly different at $\mathrm{p}=0,05$; DT, drying times (days).

Oven and sun drying, heart and sapwood and duration of drying had significant differences of moisture gain in $P$. deltoides after 25 days' time point. Interaction among drying methods, wood types and time for drying was non-significant (p.0,05) (Table 1). An increase in duration for drying resulted in higher MC than preceding time point. Initial time point for drying (i.e. 5 days) in either method recorded the lowest moisture gain, which was negligible in respective control treatment. The latter treatment at end of experiment showed significant increase in moisture gain from corresponding initial time point and was significantly different from respective drying wood at each time point (Table 3 ). 
Table 3. Comparison of means for moisture gain in Populus deltoides with oven and sun drying at different drying durations.

\begin{tabular}{|l|l|l|l|l|l|l|}
\hline & \multicolumn{4}{l|}{ Drying Methods (DM) } & Wood types \\
\hline DT & Oven drying & Control & Sun drying & Control & Sapwood & Heartwood \\
\hline 5 & $5,44 \pm 0,21 \mathrm{fg}$ & $0,47 \pm 0,06 \mathrm{j}$ & $4,88 \pm 0,23 \mathrm{gh}$ & $0,40 \pm 0,06 \mathrm{j}$ & $3,01 \pm 0,78 \mathrm{~h}$ & $2,50 \pm 0,66 \mathrm{i}$ \\
\hline 10 & $9,23 \pm 0,23 \mathrm{~d}$ & $1,39 \pm 0,15 \mathrm{i}$ & $8,66 \pm 0,22 \mathrm{~d}$ & $1,49 \pm 0,15 \mathrm{i}$ & $5,53 \pm 1,18 \mathrm{f}$ & $4,85 \pm 1,09 \mathrm{~g}$ \\
\hline 15 & $11,10 \pm 0,25 \mathrm{c}$ & $4,70 \pm 0,28 \mathrm{~h}$ & $10,70 \pm 0,25 \mathrm{c}$ & $4,46 \pm 0,41 \mathrm{~h}$ & $8,31 \pm 0,94 \mathrm{~d}$ & $7,17 \pm 0,97 \mathrm{e}$ \\
\hline 20 & $12,10 \pm 0,27 \mathrm{~b}$ & $5,92 \pm 0,24 \mathrm{f}$ & $11,89 \pm 0,23 \mathrm{~b}$ & $5,94 \pm 0,26 \mathrm{f}$ & $9,49 \pm 0,92 \mathrm{c}$ & $8,42 \pm 0,91 \mathrm{~d}$ \\
\hline 25 & $14,78 \pm 0,23 \mathrm{a}$ & $7,06 \pm 0,28 \mathrm{e}$ & $14,47 \pm 0,23 \mathrm{a}$ & $7,15 \pm 0,25 \mathrm{e}$ & $11,38 \pm 1,13 \mathrm{a}$ & $10,35 \pm 1,14 \mathrm{~b}$ \\
\hline
\end{tabular}

Values are Mean \pm SE. Means sharing same letters are not significantly different at $\mathrm{p}=0,05$; DT, drying times (days).

Table 4 shows the weight loss of sap and heartwoods of $C$. adansonii and P. deltoides after sun and oven drying at different time durations. Weight loss was more in less dried sap and heartwood of either plant species. Highest weight loss was seen in the control treatment (fresh woods) and minimum in wood dried for a longer period. A correlation between moisture content and weight loss in both types of woods of plant species also was not only positive but also highly significant $(r>0,5)$.

Table 4. Comparison of weight loss (\%) in sap and heartwoods of C. adansonii and $P$. deltoides at different time points after sun and oven drying.

\begin{tabular}{|l|l|l|l|l|l|l|l|l|}
\hline & \multicolumn{4}{|c|}{ Sun drying } & \multicolumn{3}{c|}{ Oven drying } \\
\hline DT & \multicolumn{2}{|c|}{ C. adansonii } & \multicolumn{2}{c|}{ P. deltoides } & \multicolumn{3}{c|}{ C. adansonii } & \multicolumn{1}{c|}{ P. deltoides } \\
\hline & Sapwood & Heartwood & Sapwood & Heartwood & Sapwood & Heartwood & Sapwood & Heartwood \\
\hline 25 days & $40,28 \pm 0,04 \mathrm{~b}$ & $37,08 \pm 0,64 \mathrm{~b}$ & $55,84 \pm 0,23 \mathrm{~b}$ & $53,49 \pm 0,32 \mathrm{~b}$ & $36,91 \pm 0,02 \mathrm{~b}$ & $33,91 \pm 0,02 \mathrm{~b}$ & $51,32 \pm 0,01 \mathrm{~b}$ & $48,22 \pm 0,11 \mathrm{~b}$ \\
\hline 20 & $36,34 \pm 0,02 \mathrm{c}$ & $32,93 \pm 0,31 \mathrm{c}$ & $52,46 \pm 0,24 \mathrm{c}$ & $50,12 \pm 0,45 \mathrm{c}$ & $32,14 \pm 0,01 \mathrm{c}$ & $29,14 \pm 0,01 \mathrm{~cd}$ & $47,52 \pm 0,02 \mathrm{bc}$ & $44,54 \pm 0,02 \mathrm{bc}$ \\
\hline 15 & $34,81 \pm 0,02 \mathrm{~d}$ & $31,09 \pm 0,50 \mathrm{~d}$ & $48,64 \pm 0,77 \mathrm{de}$ & $45,98 \pm 0,77 \mathrm{de}$ & $30,71 \pm 0,01 \mathrm{~d}$ & $27,71 \pm 0,01 \mathrm{~d}$ & $45,74 \pm 0,02 \mathrm{~cd}$ & $41,85 \pm 0,46 \mathrm{~cd}$ \\
\hline 10 & $31,76 \pm 0,02 \mathrm{f}$ & $28,11 \pm 0,11 \mathrm{e}$ & $46,54 \pm 0,56 \mathrm{ef}$ & $44,54 \pm 0,56 \mathrm{ef}$ & $27,83 \pm 0,01 \mathrm{e}$ & $24,83 \pm 0,58 \mathrm{e}$ & $42,37 \pm 0,26 \mathrm{de}$ & $39,39 \pm 0,19 \mathrm{~d}$ \\
\hline 5 & $28,90 \pm 0,01 \mathrm{~g}$ & $24,56 \pm 0,44 \mathrm{f}$ & $44,62 \pm 0,39 \mathrm{f}$ & $42,29 \pm 0,58 \mathrm{f}$ & $24,44 \pm 0,01 \mathrm{f}$ & $21,44 \pm 0,58 \mathrm{f}$ & $39,34 \pm 0,23 \mathrm{ef}$ & $33,07 \pm 3,16 \mathrm{f}$ \\
\hline Control & $52,33 \pm 0,16 \mathrm{a}$ & $48,78 \pm 0,40 \mathrm{a}$ & $65,55 \pm 0,74 \mathrm{a}$ & $62,55 \pm 0,74 \mathrm{a}$ & $48,47 \pm 0,04 \mathrm{a}$ & $45,30 \pm 0,43 \mathrm{a}$ & $63,78 \pm 0,86 \mathrm{a}$ & $59,77 \pm 0,96 \mathrm{a}$ \\
\hline
\end{tabular}

Values are Mean \pm SE. Means sharing same letters are not significantly different at $\mathrm{p}=0,05$; DT, drying times (days).

The results have revealed that wood absorbed moisture when placed in contact with soil and there was a linear relation of the increase in wood moisture content with weight loss. Woods dried by oven and sun drying lost weight after exposure to termites' workers, however, significantly less as compared to fresh wood which were control in this study. Weight loss was more in woods dried longer in oven and sun drying methods contradicts with an early report in which an inverse correlation was found between the treatment and wood consumption (Sheikh et al. 2010). This different can be credited to two reasons either termites species was different or method of exposing woods to termites was not in contact with soil in the field. Termites' species was same, however, the method of exposure was totally different. Placement of woods was $30 \mathrm{~cm}$ deep in soil and moisture gain in this fashion may have started the wetting of woods (i.e., having MC above threshold for feeding). O. obesus avoids wet woods, whereas in the present studies, woods were placed onto concrete surface holed for termites to reach them. Woods kept in that way also showed an increase in their moisture contents.

Subterranean termites live in the soil, or in moist wood and they need specific moisture content in woods to gain access to food. Termites favor decaying wood in moist situations within which to establish colonies as it provides them with protein and moisture (Brian 1965). Odontotermes spp. and Microtermes spp. are not restricted to wood already infected by fungi but instead can gnaw fresh wood into fragment upon which to grow fungi to feed larvae / nymphs in colony (Richardson 1993). This corroborates to present results where fresh woods were heavily attacked by termite species because fresh woods may be moist enough to allow termites' feeding freely and sufficient space in woods should be available to allow termites to reach foods which obviously not the case in wet woods. It also clearly shows that $O$. obesus requires moist wood for feeding but not wet ones. In this case, temperature or heat treated wood will not be successful to resist termites' feeding if it is in contact with soil and 
continue absorbing steadily the moisture from surroundings.

Heartwoods of either plant species were resilient to moisture gain as compared to sap woods, which indicates towards role of hydrophobic extractives as indicated by Quartey (2015). Difference between plant species can be attributed to the same reason. $C$. adansonii resisted the moisture gain.

\section{CONCLUSIONS}

It can be concluded that reduction of moisture contents of wood by heat treatment, i.e. sun drying/ oven drying, is not an appropriate method to reduce the $O$. obesus infestation. Woods ought to be kept in dry conditions to prevent moisture gain and ultimately termites' infestation. Further, woods should be treated with hydrophobic preservatives under high moist conditions.

\section{REFERENCES}

Akyildiz, M.H.; Ates, S. 2008. Effect of heat treatment on equilibrium moisture content (EMC) of some wood species in Turkey. Research Journal of Agriculture and Biological Sciences 4(6):660-665. 362.

Brian, M.V. 1965. Studies of caste differentiation in Myrmica rubra L. Insectes Sociaux 12: 347-

Clausen, C.A. 2010. Biodeterioration of wood. Chapter 14. In: Ross, R.J. (ed.), Wood handbook: wood as an engineering material. Centennial ed. Forest Products Laboratory, USDA.

Duarte, S.; Welzbacher, C.R.; Duarte, M.; Nunes, L. 2012. Assessment of thermally modified timber (TMT) through subterranean termites feeding behavior. Proceed. $6^{\text {th }}$ Eur. Conf. Wood Modification, Ljubljana, Slovenia 235-238.

Duarte, S.; Taylor, A.M.; Lloyd, J.D.; Duarte, M.; Nunes, L. 2016. Optimization of termite inground monitoring stations: An evaluation trial. Maderas-Cienc Tecnol 18(1):191-206.

Fatima, R.; Ahmed, S.; Arshad, M.; Sahi, S.T. 2015. Effect of seasoning of different woods on resistance against Odontotermes obesus (Ramb.) under laboratory and field choice and no-choice tests. BioResources 10(4):6363-6377.

Hartley, J.; Marchant, J.F. 1995. Methods of determining the moisture content of wood. Res. Div., State Forests, New South Wales. Australia. pp. 1-3.

Mantanis, G.I.; Papadopoulos, A.N. 2010. The sorption of water vapors of wood treated with a nanotechnology compound. Wood Science and Technology 44(3):515-522.

McManamy, K.; Koehler, P.G.; Branscome, D.D.; Pereira, R.M. 2008. Wood moisture content affects the survival of eastern subterranean termites (Isoptera: Rhinotermitidae) under saturated relative humidity conditions. Sociobiology 52(1):145-156.

Obataya, E. 2014. Recoverable effects of heat treatment. Conference on "Recent Advances in the Field of TH and THM Wood Treatment" May 19-21, 2014, Skelleftea, Sweden.. pp. 21-23.

Quartey, G.A. 2015. Anatomical properties of three lesser utilised Ghanaian hardwood species. Materials Sciences and Applications 6:1111-1120.

Richardson, B.A. 1993. Wood Preservation. E. \& F.N. Spon, London, 226pp. 
Scouse, A.; Kamke, F.A.; Morrell, J.J. 2015. Potential for using essential oils to protect viscoelastic thermal compression-treated hybrid poplar. Forest Products Journal 65(3/4):93-99.

Sheikh, N.; Qureshi, A.M.; Laif, M.U.; Manzoor, F. 2010. Study of temperature treated woods for the preference and first food choice by Odontotermes obesus (Isoptera: Termitidae). Sociobiology $56(2): 363-373$.

Sivrikaya, H.; Can, A.; de Troya, T.; Conde, M. 2015. Comparative biological resistance of differently thermal modified wood species against decay fungi, Reticulitermes grassei and Hylotrupes bajulus. Maderas-Cienc Tecnol 17(3):559-570.

Sponsler, R.C.; Appel, A.G. 1990. Aspects of the water relations of the Formosan and Eastern subterranean termites (Isoptera: Rhinotermitidae). Environmental Entomology 19:15-20.

Surini, T.; Charrier, F.; Malvestio, J.; Charrier, B.; Moubarik, A.; Castera, P.; Grelier, S. 2011. Physical properties and termite durability of maritime pine Pinus pinaster Ait. heat-treated under vacuum pressure. Wood Science and Technology 46:(1-3). 